\title{
ФОНЕТИЧНА ТЕРМІНОЛОГІЯ В УКРАЇНСЬКИХ ГРАМАТИКАХ ХІХ - ПОЧ. ХХ СТ.
}

\author{
ІРИНА КОЗЕЛКО \\ Львівський національний університет ім. І. Франка, Львів - Україна \\ TERMINOLOGIA FONETYCZNA W \\ GRAMATYKACH UKRAINSKICH XIX - POCZAॄTKU XX w. \\ IRYNA KOZEŁKO \\ Lwowski Uniwersytet Narodowy im. Iwana Franki, Lwów — Ukraina
}

STRESZCZENIE. W artykule przeanalizowano terminy fonetyczne obecne $\mathrm{w}$ gramatykach lat 20. i 30. XX w. Dowiedziono, iż stanowią one ciąłość w tradycji tworzenia nowoczesnych terminów fonetycznych.

\section{PHONETIC TERMINOLOGY IN UKRAINIAN GRAMMARS OF THE XIX ${ }^{\text {th }}-$ THE BEGINNING OF THE XX ${ }^{\text {th }}$ CENTURY}

\author{
IRYNA KOZELKO \\ I. Franko Lviv National University, Lviv — Ukraine
}

ABSTRACT. The article deals with phonetic terms detected in grammars of the $20 \mathrm{~s}-30 \mathrm{~s}$ of the $\mathrm{XX}^{\text {th }}$ century. They can determine the continuity of traditional formation of modern phonetic terms in the development of science.

$\mathrm{B}$ ивчення граматики української мови неможливе без знання іiі термінології. Але українська граматична термінологія не завжди була такою, як сьогодні. Вона пройшла нелегкий шлях становлення й розвитку. Цей шар лексики привертав і продовжує привертати увагу дослідників.

Період 20 - 30-ті pp. ХХ ст. вважають найяскравішим у формуванні кодифікаційних норм та засад лінгвістичної термінології, оскільки це був період найбільшого розвою українства. Неодноразово I. Огієнко - палкий борець за вивірене українське слово - наголошував на тісному зв'язку лінгвістичної термінології і народної мови. Учений закликав пам'ятати про те, що „у кожного народу, що має свою історію, має право на самостійне існуваннє, та чи інша виробленість наукової термінольогії свідчить про його культурний зріст, його культурне становище"'.

Сьогодні науковці вже окреслили шляхи, якими творилася лінгвістична термінологія, тому можемо простежити іiі становлення та нормалізацію. А. Коваль зауважує, що „надзвичайно важливий для нормування мовної практики інструктивно-регулятивний план діяльності не може бути розгорнений належним чином без об'єктивно-історичного"2. Отже, щоб простежити процес становлення та кодифікації лінгвістичних термінів, зосередимо увагу на одному з розділів науки про мову — фонетиці; простежимо, які фонетичні терміни вжи-

${ }^{1}$ І. Огієнко, Українська граматична термінольотія, Київ 1908, с. 2.

${ }^{2}$ А. Ко в а ль , Культура мови і мовлення, [в:] „Мовознавство” 1968, № 1, с. 43. 
вали укладачі й упорядники українських граматик того часу. Для аналізу використаємо підручники й посібники з граматики української мови, що виходили у світ у період XIX - поч. XX ст. в Україні й поза їі межами. Наголосимо, що в окреслений цією розвідкою час з'явилися імена вчених, які попри всілякі заборони й переслідування писали національні підручники, чим спричинилися до вироблення їі термінологічного фонду. До числа таких учених належали О. Павловський, Г. Шерстюк, С. Смаль-Стоцький, Ф. Гартнер, В. Сімович, П. Горецький, І. Шаля.

У граматичному лоні однією з перших українських граматик того часу була „Грамматика малороссійскаго нарЂчія” О. Павловського (1818), що містить дві частини, де фонетична термінологія функціонує тільки в першій частині. Тут зафіксовані такі фонетичні терміни: звук (с. 3)3, слогъ (с. 10), согласная (14), гласная (14). Зрозуміло, що це перші кроки в кодифікаційній справі; перелічені терміни відображають російськомовний вплив.

Більш повну фіксацію фонетичної термінології простежуємо в праці Г. Шерстюка „Коротка українська граматика для школи” (1907). Щодо використання термінів, то автор зізнається: „Галицькі-ж граматичні терміни я признав не всі досить вдатними та зрозумілими й через те мусів де-які з них змінить на терміни, витворені професором А. Кримським у власній граматиці"4. Опис фонетичної термінології в цій праці здійснено в двох коротких розділах „Склад” і „Звук та буква”. У розділі під назвою „Склад” автор характеризує самозвуки (с. 8), співзвуки (с. 8), наголос (с. 9), наголосний значок (с. 9), отвертий склад (c. 9), замкнений склад (с. 9); частина IV „Звук та буква” фіксує такі фонетичні терміни: звук (с. 10), тверді самозвуки (с. 10), мнякі самозвуки (с. 10), звучні співзвуки (с. 11), тихі співзвуки (с. 11), губні співзвуки (с. 11), зубні співзвуки (с. 11), піднебенні співзвуки (с. 11), гортанні співзвуки (с. 12), язичні спізвуки (с. 12), сичачі співзвуки (с. 12), ииплячі співзвуки (с. 12), плавні співзвуки (с. 12), носові співзвуки (с. 12).

Г. Шерстюк усвідомлював, що „найбільш болюче місце в нашій граматичній літературі - термінологія". Дослідник вдається до глибших роздумів над станом вироблення термінології, і як „цю неодностайність у вживанні тієї чи иншої термінології не можна вважати за щось лихе, бо кожний автор бере ту термінологію, що йому здається кращою, а иноді ще й сам витворює терміни, і тим всим дає матеріял до майбутнього вироблення одностайної найкращої термінології"5.

Зауважимо, що в підручнику Г. Шерстюка жоден із розділів не подає комплексного аналізу фонетичної термінології та не виділяє фонетики в окрему повноцінну частину граматики. Проте наведені спроби показують вплив термінологічної традиції, що простежувалась у граматиках.

Н. Москаленко стверджує, що фонетична термінологія цього періоду була вже відносно стабілізована 6 . До наслідування цієї термінології від попередників дослідниця відносить й граматичну працю Г. Шерстюка.

Фонетичні терміни піддано аналізу в західноукраїнських граматиках, зокрема в „Граматиці руської мови” (1914) С. Смаль-Стоцького та Ф. Гартнера розділ, що поєднує ці поняття, зветься звуками. Звичні самозвуки, співзвуки ав-

${ }^{3}$ Примітка. У дужках указано сторінки названого підручника; у статті дотримуємо авторської орфографії.

${ }^{4}$ Г. Шер с т ю к, Коротка українська граматика для школ, Полтава 1907, ч. I, с. 4.

${ }^{5}$ Г. Ше рстюк, Украйнська граматика для школи, Складня, Київ 1909, ч. II, с. 3.

${ }^{6}$ Н. А. Мос кале н ко, Нарис історї̈ украӥнської граматичної термінологї, Київ 1959, с. 6. 
тор замінює на голосівки (с. 5), шелестівки (с. 5), ужито й авторський фонетичний термін двозвук (с. 6) - тісні сполучення двох голосівок $;$; здійснено класифікацію звуків за різними ознаками: наголошені, ненаголошені (с. 6), шелестівки проривні (с. 7), безголосі шелестівки (с. 7), голосові шелестівки (с. 7), протиснені (с. 7), дрожачий (с. 7), носові звуки (с.7), придиховий звук (с. 7), мягкі і тверді звуки (с. 8), шипячі звуки (с. 15), визвукові безнаголосні голосівки (с. 15), голосівки без наголосу (с. 20); решта фонетичних термінів позначають різні фонетичні зміни: звуки мовні (с. 5), склади (с. 9), наголос (с. 9), рухомий наголос (с. 9), зміни звукові (с. 12), уподібненє шелестівок, випад, вставка (с. 12), мягченє (с. 14), мягченє першого ступня (с.15), мягченє другого ступня (с. 15), зміни в визвуку (с. 18), зміни в назвуку (с. 18), опуст і вставка голосівок (с. 20), роззї (с. 21) - уникання зустрічі двох голосівок, перезвукіканє (с. 21), повноголос (с. 22), переставка з зміною голосівки (с. 23), перезвук словотворний (с. 24), оскільки відбувається зміна однієї літери на іншу, під час творення нового слова, переставка звуків і складів (с. 26), милозвучність (с. 26). Як бачимо, „фонетична термінологія почала вироблятись на рідномовній основі і досить швидко найголовніші терміни почали стабілізуватися. Але ця стабілізація не була стійкою та тривалою, і до 1917 р. фонетична термінологія зазнала істотних змін”8.

Почнімо розгляд із граматики (1919р.) одного 3 „найбільших наддністрянців” (О. Горбач) - Василя Сімовича, що дасть змогу з'ясувати повноту системного викладу розділу в указаній граматиці, а також виявити терміни, що пройшли етап кодифікації в сучасній літературній мові. Зауважимо, що В. Сімович свого часу уклав комплексно-фундаментальну працю, де подав осмислення норм української мови та термінологію іiі мовознавчих розділів. Заслуга вченого полягала насамперед у тому, що він зафіксував власне бачення граматичної системи української мови, незважаючи на обмеженість граматичної інформації, оскільки, як писав учений, „де їх набрати, тих матеріялів". Мовознавець зібрав фактичний матеріал та подав його читачеві: „Практична ціль роботи у найкоротшому часі зазнайомити читачів із найважнїщими законами української мови та прикласти ті закони для життя".

Отже, В. Сімович накреслив національний грунт творення української лінгвістичної термінології. Наголосимо також, що вагому роль для утвердження фонетичної термінології відіграла „Граматика української мови” В. Сімовича, оскільки вчений був послідовником свого вчителя С. Смаль-Стоцького. Додамо, що лінгвістичний вишкіл В. Сімовича спонукав його створити працю, що відтворювала би практичний аспект граматики, тому в „Граматиці української мови” він коротко зібрав і описав "найважнїще, що треба би знати у практиці"9. Ця праця має високий науковий рівень термінології, про що пише й сам автор: „Майже всї граматики, які появили ся в нас ув останнїх двох роках, я мав під руками, докладно їх переглянув і використав, що міг, використав і граматичну термінольогію"9. Учений приділяв значну увагу також і тлумаченню граматичної термінології, якою послуговувався, оскільки їі було репрезентовано в тогочасних підручниках, граматиках неоднозначно, а подекуди терміни відзначалися багатозначністю, тому В. Сімович у передмові до „Граматики української мови” наголошує на тому, що ,розяснення граматичних назв, які виведено методичним способом так, що тими вказівками може користуватись і вкраїнський

\footnotetext{
${ }^{7}$ С. С маль-С тоцький, Ф.Гартнер, Граматика руської мови, Відень 1914, с. 6.

${ }^{8}$ Н. А. Москаленко, Зазнач. джерело, с. 62-63.

${ }^{9}$ В. Сі мо в и ч, Граматика украӥнської мови, Ляйпціг 1919, с. 4.
} 
учитель, і читач із народа, який цікавить ся українською граматикою"10. Як бачимо, заклики В. Сімовича до коректного вживання „граматичних назв” - лінгвістичних термінів - мали чималий сенс. Лінгвіст усвідомлював значення традиції для вироблення й удосконалення лінгвістичних термінів. Перший розділ граматики В. Сімовича фіксує фонетичні терміни й називається Звуки. Зазначимо, що автор уводить поняття звучня, що відповідає сучасному „фонетика”, це „та частина граматики, яка обіймає звукові закони”11. У цій граматиці функціонують такі терміни фонетики: звучня $і$ звукові закони (с. 38), фонетичний правопис (с. 38), украӥнська азбука або абетка (с. 39), звуки (с. 39), звукові закони (с. 39), голосові шелестівки (с. 40), безголосі шелестівки (с. 40), шелестівка (с. 42), голосівка (с. 42), мнягчення (с. 44), нове мнягчення (с. 44), зубні шелестівки (с. 44), плавкі шелестівки (с. 44), губні шелестівки (с. 44), мнякі голосівки (с. 45), середнє л (с. 45), старе мнягчення (с. 49), шипучі шелестівки (с. 49), заднєпіднебінні (с. 49), мняке „ц” (с. 51), українське „i” (с. 52), відчинений, зачинений склад (с. 53), ікання (с. 53), одчинений склад (с. 54), вставне, приставне $i$ (с. 59), сична або шипуча шелестівка (с. 59), черговання „, в" із „, ,”, з „й” на початку слова (с. 61), двозвук (с. 61), назвучне „, шелестівок (с. 63), назвук слів (с. 63), назвучні шелестівки (с. 63), зустріч шелестівок (с. 65), випад шелестівок (с. 65), вставка голосівок (с. 68), стягнення шелестівок (с. 68), приподібнення шелестівок (с. 69), зустріч голосівок (роззїв) (с. 72), наголошені (с. 73), безнаголосні голосівки або ненаголошені голосівки (с. 73), визвук (с. 75), визвучна голосівка (с. 76), гармонійне приподібнення голосівок (с. 79), чужі звуки (с. 80). Усі наведені терміни супроводжені авторськими поясненнями та практичним коментарем. Серед перелічених є й такі, що відтворюють паралельні форми: відчинений склад (с. 53), одчинений склад (с. 54), сична або шипуча шелестівка (с. 59), безнаголосні голосівки або ненаголошені голосівки (с. 73); більшість термінів традиційно використовують у західноукраїнських граматиках, порівн.: шелестівка (с. 42), голосівка (с. 42), двозвук (с. 61), назвучне , $i$ ” (с. 61), зустріч голосівок (роззї), (с. 72), визвук (с .75), визвучна голосівка (с. 76) та ін.

Виокремимо й тенденцію до появи власне авторських дефініцій на позначення фонетичних одиниць мови, зокрема й у П. Горецького, І. Шаля, напр.: тихі звуки, середні звуки, чисті голосні звуки, середня вимова. У граматиці „Українська мова: практично-теоретичний курс" (1926) П. Горецького та І. Шаля також виокремлено розділ мовознавства, що вивчає звуки української мови, який названо фонетикою. Автори праці зазначили, що курс вивчення української мови повинен базуватися на практичній роботі, тому прагнули мінімізувати „по змозі теоретизацію питань; тим-то автори свідомо обминули де-які явища (напр., acuміляц̧ія, дисиміляція та ин.)"'12. Граматика налічує близько 49 фонетичних термінів. Ці терміни закріпилися й знайшли практичне застосування в теперішній лінгвістичній науці, напр., голосні звуки (с. 5), приголосні звуки (с. 5), наголос (с. 5), фонеми (с. 5), м'які, тверді звуки (с. 7), шиплячий звук (с. 10), принцип правопису звуковий або фонетичний (с. 11), історичний принции (с. 11), принцุип аналогї̈ або принцип етимологї (с. 12), закритий склад (с. 14), ненаголошений звук (с. 18), відкритий склад (с. 20), губні звуки (с. 20) та ін.

${ }^{10}$ Там само, с. $5,7,38$.

11 Там само.

${ }^{12}$ П. Гор е ць к ий, І.Ш а я , Украӥнська мова: практично-теоретичний курс, Підручник для вищих шкіл, Київ 1926, с. 3. 
Лінгвістичні терміни на позначання фонетичних одиниць мови пройшли відповідний етап кодифікації й на поч. XX ст., оскільки фонетика поступово почала виділятися в окремий мовознавчий розділ та набувати детального опису.

Дослідниця історії української граматичної термінології Н. Москаленко наголосила, що „фонетична термінологія, вживана в різних граматиках, граматках і мовознавчих працях того періоду, була досить строкатою"13.

Дослідження фонетичної термінології в граматиках О. Павловського, Г. Шерстюка, С. Смаль-Стоцького, Ф. Гартнера, В. Сімовича, П. Горецького, I. Шаля є цікавими, оскільки дають змогу виявити наповненість фонетичної терміносистеми поч. XX ст. Зауважимо також, що ці терміни переважно мають прозору мотивованість і дослівно розкривають зміст позначуваних понять.

\footnotetext{
${ }^{13}$ Н. А. Москаленко, Зазнач. джерело, с. 44.
} 